\title{
ANALISIS PEMBIAYAAN DENGAN PRINSIP MURABAHAH PADA PT. BANK SUMUT SYARIAH CABANG MEDAN
}

\author{
Fitriyani Panjaitan ${ }^{1}$, Andri Soemitra ${ }^{2}$ \\ ${ }^{1}$ Universitas Islam Negeri Sumatera Utara, e-mail: fitriyanipanjaitan01@ gmail.com \\ ${ }^{2}$ Universitas Islam Negeri Sumatera Utara
}

\section{ARTICLE INFO}

Article history:

Received 27 September 2021

Received in revised form 30 September 2021

Accepted 25 Oktober 2021

Available online 29 Oktober 2021

\begin{abstract}
This study discusses the analysis of financing with the principle of murabahah at PT. Bank Sumut Syariah Medan. The murabahah contract is the sale and purchase of goods at the original price with an additional profit agreed upon by the seller, who must notify the price of the product he purchased and determine a level of profit in addition to it. The research method used is descriptive qualitative with data collection techniques through interviews and observations. The results showed that the murabahah financing mechanism at Bank Sumut Syariah Brigjen Katamso Medan can be used by all human beings where the type of business must remain in accordance with Islamic sharia and in order to minimize the risk of default the bank provides action in the form of supervision.
\end{abstract}

Keywords: The Murabahah Finacing, Islamic Bank

\footnotetext{
Abstrak

Penelitian ini membahas tentang analisis pembiayaan dengan prinsip murabahah pada PT. Bank Sumut Syariah Cabang Medan. Akad murabahah merupakan jual beli barang pada harga asal dengan tambahan keuntungan yang disepakati penjual harus memberi tahu harga produk yang ia beli dan menentukan satu tingkat keuntungan sebagai tambahanya. Metode penelitian yang digunakan adalah kualitatif deskriptif dengan teknik pengumpulan data melalui wawancara dan observasi. Hasil penelitian menunjukan bahwa mekanisme pembiayaan murabahah pada Bank Sumut Syariah Brigjen Katamso Medan bisa digunakan oleh seluruh umat beragama dimana jenis usaha harus tetap sesuai dengan syariah islam dan guna meminimalisir risiko pada gagal bayar pihak bank memberikan tindakan berupa pengawasan.

Kata Kunci: Pembiayaan Murabahah, Bank Syariah

\section{PENDAHULUAN}

Saat ini perkembangan industri perbankan semakin meningkat pesat dari waktu ke waktu. Sektor perbankan mengalami banyak perubahan baik dari segi persaingan antar bank negeri maupun swasta. Oleh karena itu pihak perbankan akan selalu memperbaiki sisitem kinerjanya untuk menghadapi tuntutan yang ada di sektor perbankan dalam meraih produktivitas organisasi. Bank merupakan lembaga keuangan yang menjalankan usahanya dengan cara mengumpulkan dana dari beberapa sumber dan memberikan pinjaman kepada nasabahnya serta memberikan pelayanan jasa lainnya. Berdasarkan prinsip usaha bank dibedakan menjadi dua kelompok yaitubank konvensional yang menjalankan usahanya berdasarkan system bunga dan bank syariah berdasarkan margin. Menurut undang - undang no. 10 tahun 1998 bank syariah merupakan bank umum yang melaksanakan
} 
kegiatan usahanya berdasarkan prinsip yang dalam kegiatannya memberikan jasanya dalam lalu lintas pembayaran.

Penulis harus memastikan bahwa tulisannya tidak mengandung unsur plagiasi. Artikel yang sudah terbit sebagai prosiding, tidak diterima untuk terbit di jurnal ini tanpa melalui proses lebih lanjut untuk melengkapi tulisan dan data hasil akhir penelitian.

Oleh karena itu untuk menjalankan usahanya selalu mempertimbangkan halal dan haram menurut hukum islam. Bank syariah berpedoman dan berlandaskan pada ajaran islam yangberpegang pada Alquran dan hadist yang menitik beratkan usahanya dengan prinsip keadilan,amanah,kemitraan,transparansidan saling menguntungkan baik bagi bank maupun bagi nasabah serta meniadakan unsur ribadan tidak membiayai usaha yang diharamkan dan menimbulkan kemudharatan bagi masyarakat luas.

Sementara itu bank konvensional lebih mengutamakan profit/laba disamping kerjasama dalam mengatasi masalah keuangan. PT. Bank Sumut Syariah Cabang Medan merupakan salah satu bank dengan berbagai produk. Dimana dalam menjalankan operasinya telah diperoleh laba yang meningkat sesuai dengan perkembangan waktu. Salah satu produk layanan perbankan penting yang dijalankan bank syariah bertindak sebagai mediator atau penghubung antara pihak pemilik dana (pemegang saham) dan nasabah dana (investor) dengan pihak yang membutuhkan modal atau dana (pengusaha dan masyarakat konsumen). Prinsip yang dijalankan bank syariah salah satunya adalah jual beli angsuran yang dikenal dengan Bai'almurabahah yaitu jual beli barang dengan harga asal dengan tambahan keuntungan yang disepakati.

Pada produk pembiayaan ini PT. Bank Sumut Syariah Cabang Medan memiliki beberapa produk kredit untuk nasabah. Para pejabat bank selalu dituntut kehati - hatian dalam pemberian pembiayaan, karena kalau terjadi kesalahan dalam melakukan analisa dalam pemberian pembiayaan, besar kemungkinan pembiayaan nantinya akan menjadi pembiayaan masalah atau macet dan apabila hal ini terjadi akan mengundang persoalan yang lebih berat dikemudian hari.Dari uraian diatas dinyatakan bahwa dalam pemberian pembiayaan kepada pengusaha mikro dan kecil sangat diperlukan sekali petugas pembiayaan yang baik dan teliti. Untuk itu pengetahuan untuk menganalisa pembiayaan bagi pengusaha mikro dan kecil bagi PT. Bank Sumut Syariah Cabang Medan diperlukan agar pemberian pembiayaan kepada nasabah kecil dapat berjalan dengan lancar dan tepat sasaran.

Pada penulisan artikel ini terdapat beberapa rumusan masalah yaituBagaimana mekanisme pemberian kredit pada PT. Bank Sumut Syariah Cabang Medan dan Bagaimana bentuk pengawasan pada pembiayaan dengan prinsip murabahah pada PT. Bank Sumut Syariah Cabang Medan. Berdasarkan uraian diatas, maka penulis berkeinginan untuk meneliti mengenai sistem pembiayaan pada bank syariah yang berdasarkan prinsip murabahah yang berjudul "Analisa Pembiayaan Dengan Prinsip Murabahah Pada PT. Bank Sumut Syariah Cabang Medan”.

\section{METODOLOGI PENELITIAN}

\subsection{Jenis Penelitian}

Penelitian ini merupakan penelitian kualitatif, metode kualitatif adalah penelitian yang bermaksud untuk memahami fenomena tentang apa yang dialami oleh subjek penelitian misalnya perilaku, persepsi, motivasi, tindakan secara holistik dan dengan cara deskripsi dalam bentuk katakata dan bahasa pada suatu konteks khusus yang alamiah dan dengan memanfaatkan berbagai metode alamiah. Sehingga dapat disimpulkan bahwa penelitian kualitatif merupakan sebuah metode penelitian dimana terdapat proses memahami fenomena yang terjadi melalui berbagai metode ilmiah dan disimpulkan dengan bentuk deskripsi berupa kata-kata.

\subsection{Sumber Data}

Smber data utama penelitian kualitatif adalah kata-kata dan tindakan, selebihnya adalah data tambahan seperti dokumen dan lain-lain. Sesuai dengan metode penelitian yang digunakan, maka jenis data yang digunakan dalam penelitian ini meliputi:

\section{a) Sumber Data Primer}

Sumber data primer adalah sumber data yang langsung diperoleh oleh pengumpul data. Sumber data primer diperoleh penulis dari kegiatan observasi, wawancara dan dokumentasi langsung pada setiap narasumber yang terkait. 


\section{b) Sumber Data Sekunder}

Sumber data sekunder merupakan sumber yang tidak langsung memberikan data kepada pengumpulan data misalnya lewat orang lain atau dokumen. Dalam penelitian ini sumber data sekunder yang digunakan untuk mendukung informasi dari sumber data primer.

\subsection{Teknik Pengumpulan Data}

Teknik pengumpulan data merupakan salah satu langkah terpenting dalam penelitian. Tujuan dari penelitian adalah untuk mendapatkan data. Tanpa mengetahui teknik pengumpulan data, maka peneliti tidak akan mendapatkan data sesuai dengan standar data yang diterapkan. Prosedur yang digunakan dalam pengumpulan data pada penelitian ini adalah teknik wawancara dan observasi.

\section{a) Wawancara}

Wawancara dilakukan sebagai teknik pengumpulan data apabila peneliti ingin melakukan studi pendahuluan untuk menemukan permasalahan yang harus diteliti sekaligus respon dari narasumber secara mendalam. Wawancara merupakan suatu percakapan dengan maksud tertentu yang dilakukan oleh dua pihak antara pewawancara (interviewer) sebagai pihak yang mengajukan pertanyaan dengan terwawancara (interviewee) sebagai pihak pemberi jawaban.

\section{b) Observasi}

Observasi adalah dasar semua ilmu pengetahuan. Para peneliti hanya dapat melakukan kegiatan penelitian berdasarkan data yang diperoleh dari hasil observasi

\subsection{Teknik Analisis Data}

Adapun Langkah-langkah analisis data yang akan dikembangkan pada penelitian ini adalah sebagai berikut:

1) Data dari hasil wawancara, persentasi hasil pengamatan

2) Data yang sudah diorganisir ditentukan temanya

3) Mencari keterkaitan antar tema

4) Interpretasi atas temuan sesuai dengan keterkaitan antar tema dengan menggunakan beberapa teori yang relevan.

\section{HASIL DAN PEMBAHASAN}

\subsection{Mekanisme Pembiayaan Murabahah pada Bank Sumut Syariah Brigjen Katamso Medan}

Berdasarkan hasil dari pengamatan penulis selama melakukan magang di Bank Sumut Syariah Medan diketahui bahwa mekanisme pengajuan pembiayaan murabahah umumnya relatif sama dengan bank lainya. Terdapat hal berbeda dari perbankan syariah lainya yaitu pada proses perlengkapan berkas pengajuan pembiayaan murabahah. Pembiayaan murabahah pada Bank Sumut Syariah Brigjen Katamso Medan memiliki beberapa produk seperti iB Murabahah Cicil Emas dan pembiayaan KPR iB Griya. Proses awal pengajuan pembiayaan murabahah adalah pemberian penjelasanoleh Customer cervicer kepada calon mudharib tentang persyaratan dan sistem bagihasil yang diterapkan oleh Bank Sumut Syariah Brigjen Katamso Medan.

Setelah semua berkas persyaratan pembiayaan diserahkan, CS akan memberikan tanda terimah dan mencatat kedalam daftar survey dan memberikanberkas permohonan pembiayaan tersebut kepada account officeruntuk segeradilakukan rangkaian kegiatan survei yang nantinya akan dibahas dalam rapat komite pembiayaan untuk menentukan keputusan pembiayaan.Pertimbangan tersebut dilakukan oleh divisi analisis atau account officer dan pejabat operasional serta bagian administrasi.

Bisnis dan usaha yang dilaksanakan bank syariah tidak lepas dari kriteriasyariah. Karena itu bank syariah tidak akan mungkin membiayai usaha yangterkandung didalamnya hal-hal yang diharamkan. Dengan kata lain, terdapat sejumlahbatasan dalam hal pembiayaan. Tidak semua proyek atau objek pembiayaan dapatdidanai melalui dana bank syariah, namun harus sesuai dengan kaidah-kaidahsyariah.Dalam perbankan syariah, suatu pembiayaan tidak dapat disetujui sebelumdipastikan beberapa hal pokok, di antaranya sebagai berikutobjek pembiayaan halal atau haram, proyek menimbulkan kemudharatan dalam masyarakat, proyek termasuk perbuatan yang melanggar kesusilaan, proyek berkaitan dengan perjudian, usaha tersebut berkaitan dengan industri senjata yang ilegal, proyek merugikan syiat islam, baik secara langsung maupun tidaklangsung. Selain itu, pola hubungan antara bank dengan nasabah bersifat kemitraan, dimana

JURNAL ILMIAH MANAJEMEN DAN KEWIRAUSAHAAN Vol.1, No.2, Oktober 2021, pp. 162 - 166 
pada satu sisi nasabah merupakan penyandang dana atas usaha bank syariah disisi lain nasabah merupakan pengelola atas bank syariah yang sebagian besar juga merupakan dana nasabah.

4.2 Pengawasan Pembiayaan Murabahah pada Nasabah di Bank Sumut Syariah Brigjen Katamso Medan

Risiko pembiayaan adalah resiko akibat kegagalan nasabah atau pihak lain dalam memenuhi kewajiban kepada bank sesuai dengan perjanjian yang disepakati.salah satu yang termasuk dalam kelompok risiko pembiayaan adalah risiko konsentrasi pembiayaan. Risiko konsenrtasi pembiayaan merupakan risiko yang timbul akibat akibat terkonsentrasinya penyediaan dana kepada satu pihak atau sekelompok pihak, industri, sektor, dana atau area geografis tertentu yang berpotensi menimbulkan kerugian cukup besar yang dapat mengancam kelangsungan usaha bank.

Risiko pembiayaan dapat bersumber dari berbagai aktivitas bisnis bank. Pada sebagian besar bank, pemberian pembiayaan merupakan sumber risiko kredit yang terbesar. Dengan adanya resiko yang terkandung dalam setiap pemberian pembiayaan baik resiko bagi pemberian pembiayaan maupun bagi pihak penerima pembiayaan, maka dalam rangka pengamanan terhadap pembiayaan yang disalurkan diperlukan suatu aktifitas pengawasan pembiayaan.

Pengawasan pembiayaan atau kredit adalah salah satu fungsi manajemen dalam usahanya untuk penjagaan dan pengamanan dalam pengelolaan kekeyaan bank dalam bentuk pembiayaan atau yang lebih baik dan efisien guna menghindarkan terjadinya penyimpangan-penyimpangan dengan cara mendorong dipatuhinya kebijaksanaan-kebijaksanaan pembiayaan yang telah ditetapkan serta mengusahakan penyusunan administrasi yang benar.

Langkah-langkah penetapan risiko ini diawali dengan melakukan analisa pembiayaan. Menurut analisis penulis pada saat magang di bank terdapat beberapa pendekatan pembiayaan yang dapat diterapkan oleh Bank Sumut Syariah Brigjen Katamso Medan dalam kaitannya dengan pembiayaan yang dilakukan:

$>$ Pendekatan jaminan, artinya dalam memberikan pembiayaan bank harusmemperhatikan kualitas dan kuantitas jaminan yang dimiliki oleh peminjam.

$>$ Pendekatan karakter, dimana Bank memenuhi secara sungguh-sungguhterkait dengan karakter nasabah

> Pendekatan kemampuan, dimana Bank menganalisa kemampuan nasabah untuk melunasi pembiayaan yang telah diambil.

$>$ Pendekatan studi kelayakan pembiayaan, yaitu dengan memperhatikankelayakan usaha yang dijalankan oleh nasabah peminjam.

\section{KESIMPULAN DAN SARAN}

Mekanisme pembiayaan murabahah pada Bank Sumut Syariah Brigjen Katamso Medan tidak berpatokan pada nasabah yang beragama muslim saja banyak nasabah yang beragama non muslim yang menerima pembiayaan murabahah namun bank melihat dari jenis usaha yang berlaku sesuai dalam Islam. Pada umumnya prosedur kelayakan pembiayaan di Bank Sumut Syariah Brigjen Katamso Medan menerapkan prinsip 5C, selain itu bank juga harus memeriksa BI cheking yang berfungsi untuk melihat data kredit nasabah di bank lain.Bank Sumut Syariah Brigjen Katamso Medan melakukan pengawasan kepada nasabah yang telah memperoleh pembiayaan murabahah dengan cara monitorring yaitu marketing secara langsung mendatangi nasabah untuk menagih nasabah dan manganalisa bagaimana kelancaran usaha yang dijalankan oleh nasabah, dan memberikan wejangan kepada nasabah agar usaha yang dijalankan oleh nasabah semakin berkembang.

\section{SARAN}

Bank Sumut Syariah sebagai salah satu lembaga keuangan atau pihak penyedia produk pembiayaan murabahah harus mampu melakukan pendekatan dau arah sehingga tercipta hubungan harmonis dengan para debiturnya yang dilandasi pemikiran dan sikap saling menghormati, saling membutuhkan dan satu sama lain mempunyai saling ketergantungan. Pengusah membutuhkan pembiayaan untuk meningkatkan usahanya, demikian pula bank membutuhkan pengusaha untuk memutarkan uangny amaka bank tidak boleh hanya bersikap menunggu, tetapi harus menunggu bersikap proaktif. 


\section{DAFTAR PUSTAKA}

[1] Lexy J Moleong, Metode Penelitian Kualitatif (Bandung: PT Remaja Rosdakarya, 2017).

[2] Sugiyono, Metode Penelitian Kualitatif, Kuantitatif Dan R\&D (Bandung: Alfabeta, 2016).

[3] Ascarya. Akad Dan Produk Bank Syariah. Jakarta: PT Raja Grafindo Persada, 2007.

[4] "Situs resmi bank sumut: https://www.banksumut.co.id/, [ diakses Agustus. 29, 2021].

[5] Moleong, Lexy J. Metode Penelitian Kualitatif. Bandung: PT Remaja Rosdakarya, 2017.

[6] Muhammad. Manajemen Keuangan Syariah. Yogyakarta: STIM YKPN, 2014.

[7] Putri, Eskasari, and Arief Budhi Dharma. "Analisis Perbedaan Kinerja Keuangan Antara Bank Konvensional Dengan Bank Syariah.” Riset Akuntansi Dan Keuangan Indonesia 1, no. 2 (2016): 98-107. https://doi.org/10.23917/reaksi.v1i2.2734.

[8] Sugiyono. Metode Penelitian Kualitatif, Kuantitatif Dan R\&D. Bandung: Alfabeta, 2016.

[9] Suhendi, Hendi. Fiqih Muamalah. Jakarta: PT Raja Grafindo Persada, 2010. 